\title{
Effects of nerve growth factor (NGF) on blood vessels area and expression of the angiogenic factors VEGF and TGFbetal in the rat ovary
}

\author{
Marcela Julio-Pieper ${ }^{1,2}$, Hernán E Lara ${ }^{2}$, Javier A Bravo ${ }^{2}$ and \\ Carmen Romero*1
}

Address: ${ }^{1}$ Laboratory of Endocrinology and Reproductive Biology, Hospital Clínico Universidad de Chile, Santiago, Chile and ${ }^{2}$ Laboratory of Neurobiochemistry, Faculty of Chemical and Pharmaceutical Sciences, Universidad de Chile, Santiago, Chile

Email: Marcela Julio-Pieper - mjulio@ciq.uchile.cl; Hernán E Lara - hlara@ciq.uchile.cl; Javier A Bravo - jbravo@ciq.uchile.cl; Carmen Romero* - cromero@redclinicauchile.cl

* Corresponding author

Published: 10 November 2006

Reproductive Biology and Endocrinology 2006, 4:57 doi:10.1 186/1477-7827-4-57

This article is available from: http://www.rbej.com/content/4/I/57

(C) 2006 Julio-Pieper et al; licensee BioMed Central Ltd.

This is an Open Access article distributed under the terms of the Creative Commons Attribution License (http://creativecommons.org/licenses/by/2.0), which permits unrestricted use, distribution, and reproduction in any medium, provided the original work is properly cited.

\begin{abstract}
Background: Angiogenesis is a crucial process in follicular development and luteogenesis. The nerve growth factor (NGF) promotes angiogenesis in various tissues. An impaired production of this neurotrophin has been associated with delayed wound healing. A variety of ovarian functions are regulated by NGF, but its effects on ovarian angiogenesis remain unknown. The aim of this study was to elucidate if NGF modulates I) the amount of follicular blood vessels and 2) ovarian expression of two angiogenic factors: vascular endothelial growth factor (VEGF) and transforming growth factor beta I (TGFbetal), in the rat ovary.

Results: In cultured neonatal rat ovaries, NGF increased VEGF mRNA and protein levels, whereas TGFbetal expression did not change. Sectioning of the superior ovarian nerve, which increases ovarian NGF protein content, augmented VEGF immunoreactivity and the area of capillary vessels in ovaries of prepubertal rats compared to control ovaries.

Conclusion: Results indicate that NGF may be important in the maintenance of the follicular and luteal vasculature in adult rodents, either indirectly, by increasing the expression of VEGF in the ovary, or directly via promoting the proliferation of vascular cells. This data suggests that a disruption on NGF regulation could be a component in ovarian disorders related with impaired angiogenesis.
\end{abstract}

\section{Background}

Angiogenesis is an essential process in follicular development and luteogenesis $[1,2]$. Once the proliferation of new blood vessels is complete, a rapid capillary regression takes place in the non-fertile cycle which suggests a delicate coordination between angiogenesis inducers and inhibitors [3]. The intervention of ovarian vascularization has an adverse effect on the growth of the dominant follicle, the ovulation and the functioning of the corpus luteum and its ability to secrete progesterone $[1,4]$.

The regulation of cyclic angiogenesis in the ovary is commanded by a variety of growth factors; vascular endothelial growth factor (VEGF) playing a major role by 
stimulating vessel hyperpermeability, endothelial cell proliferation and migration [5]. Several splicing isoforms are generated from VEGF gene, and the proteins reach endothelial cells either by difussion of the shorter isoforms (VEGF 121, VEGF 165) or following proteolitic cleavage of longer ones (VEGF 189, VEGF 206) [3]. The mRNAs for the isoforms of 121 and 165 aminoacids are dominant in normal human ovaries [5]. In rodents, VEGF isoforms are one aminoacid shorter than in human, and have a similar distribution and function [6,7]. Another molecule that modulates angiogenesis is the transforming growth factor beta 1 (TGF $\beta 1$ ), being essential for matrix remodeling, vessel stabilization and pericyte differentiation. TGF $\beta 1$ deficient mice have impaired vessel wall integrity $[8,9]$. In the human ovary, follicular cells express TGF $\beta 1$, which has proliferative and differentiation effects on granulosa cells $[10,11]$. It also increases the size of follicles from adult mice [12]. In the hamster ovary, the mRNAs for TGF $\beta$ receptors are cyclically regulated by gonadotropins and ovarian steroids, increasing their levels as the follicle develops during the estral cycle [13].

Another important growth factor involved in ovarian physiology is the nerve growth factor (NGF). Mammalian ovary expresses the neurotrophin and both the high- and the low-affinity receptor for NGF (trkA and p75, respectively) [14-16]. In neonatal rat ovaries, the expression of follicular stimulating hormone (FSH) receptors is induced by NGF [17]. Immunoneutralization of NGF during early postnatal life of the rat results in undersized antral follicles, delayed puberty and disrupted estrous cyclicity [18]. TrkA and NGF are transiently expressed in preovulatory follicles in the first preovulatory surge of gonadotropins at puberty in the rat. The use of a neutralizing antibody to NGF or pharmacological blockade of trkA tyrosine kinase activity targeted to one ovary resulted in the ipsilateral inhibition of ovulation [19].

Although NGF promotes angiogenesis and/or induces the expression of angiogenic molecules in several tissues, such as skin, muscle, cornea, arteries [20-23] and the immunoneutralization of this neurotrophin delays the reparative neovascularization of lesions in the mice [21], the effects of NGF on ovarian angiogenesis remain unexplored. This study investigates the role of NGF in regulating the expression of the angiogenic factors VEGF and TGF $\beta 1$, and the area of blood vessels in the rat ovary. Gonadotropins can upregulate different angiogenesisrelated parameters in the ovary [24-26]; hence, to avoid this influence, we selected early stages of rat ovarian life as a model, when the tissue has not become gonadotropindependent [27].

\section{Methods Animals}

Sprague Dawley rats obtained from the Faculty of Chemical and Pharmaceutical Sciences, Universidad de Chile were housed under controlled conditions of temperature $\left(21^{\circ} \mathrm{C}\right)$ and light $(12 \mathrm{~h}$ of light, $12 \mathrm{~h}$ of darkness; lights on from 0800-2000 h). Food and drinking water were provided ad libitum. All the protocols for animal care and use included in this study were approved by the institutional review board of the Faculty of Chemical and Pharmaceutical Sciences, Universidad de Chile.

\section{Organ culture}

Ovaries from 2 day old rats were dissected under aseptic conditions, placed on sterile lens paper, and cultured on plastic supports at the interface of air/culture medium [28], under an atmosphere of 5\% CO2. For histochemical studies, one ovary per well was utilized, and for mRNA studies, three glands per well were cultured. Considering this, for an $\mathrm{n}=5,20$ pups were utilized for each incubation point. Ovaries were cultured in 24-well plates (Becton Dickinson, USA); each well contained 1 ml DMEM: F12 (50\% vol/vol, Sigma Chemicals, St Louis, MO, USA) medium supplemented with sodium bicarbonate (600 $\mathrm{mg} / \mathrm{l}$, Sigma Chemicals, St Louis, MO, USA), penicillin (50 mg/l, Laboratorio Chile, Santiago, Chile), gentamycin ( 80 mg/l, Andrómaco, Santiago, Chile), streptomycin (50 $\mathrm{mg} / \mathrm{l}$, Laboratorio Chile, Santiago, Chile) and ketoconazol (5 mg/l, Laboratorio Chile, Santiago, Chile). The ovaries were stimulated with NGF $100 \mathrm{ng} / \mathrm{ml}$ (Sigma Chemicals, St Louis, MO, USA). The optimal dose of NGF was established by previous studies from our group [17]. The contralateral ovaries cultured with medium alone were used as controls. The times of culture were 2, 4, 8 and $24 \mathrm{~h}$. In the case of mRNA studies, the ovaries were collected and stored at $-80^{\circ} \mathrm{C}$ until RNA extraction. The ovaries collected for immunohistochemistry were fixed in Bouin's fixative.

\section{Ovary denervation}

We used 16 prepuberal rats of 23-24 day old (body weight $60 \mathrm{~g}$ aprox.). They were anaesthetized with isoflurane $1 \% \mathrm{v} / \mathrm{v}, 2.5 \mathrm{l} / \mathrm{min}$ (Baxter Healthcare Co, Guayama, Puerto Rico). The dissection of the superior ovarian nerve (SON) was performed in both ovaries under aseptic conditions through a single dorsal midline incision. This procedure has shown to induce an increase of NGF within the gland [29]. Because denervation induces hypertrophy of the contralateral ovary [30], controls consisted in different animals submitted to a simulated operation. The ovaries were collected three days later (from a total of 6 rats; 3 controls and 3 denervated) or six days later (from a total of 10 rats; 5 controls and 5 denervated), and stored at $80^{\circ} \mathrm{C}$ for mRNA studies, or fixed in Bouin's fixative for histochemical procedures. The time for ovary harvesting 
after denervation was established by previous studies from our group [29].

\section{Immunohistochemistry}

Immunohistochemical detection of VEGF and TGF $\beta 1$ in denervated ovaries and cultured tissues was performed as follows: the ovaries were fixed by immersion in Bouin's fixative, embedded in paraffin, serially sectioned at $4 \mu \mathrm{m}$ and processed for immunohistochemistry using polyclonal antibodies from Santa Cruz Biotechnology (anti-VEGF [C-1], sc-7269 and anti-TGF $\beta 1$ [V] sc-146, both in a 1:50 dilution). Tissue sections were incubated overnight at $4{ }^{\circ} \mathrm{C}$ with the antibody and the immunoreaction was developed the next day using the NBT-BCIP procedure (Sigma Chemicals, St Louis, MO, USA) for VEGF in neonatal rat ovaries, or the DAB procedure (LabVision Co, Freemont CA, USA) for the rest of the detections. Controls consistent of adjacent sections incubated without the primary antibody, or sections incubated with the antibody preabsorbed with the corresponding ligand showed no staining, proving the specificity of the immunoreaction. Whenever a well defined mark was obtained, cell counting was performed by three independent observers and the data were expressed as H-Score. The H-Score is the sum of the proportion of cells showing different degrees of reactivity, and was calculated as follows: 0 times the \% of negative cells +1 time the $\%$ of weakly positive cells + 2 times the $\%$ of moderately positive cells +3 times the $\%$ of strongly positive cells. The $\mathrm{H}-\mathrm{Score}$ ranges from $0-300$, being the maximum score representative of a $100 \%$ of cells with strong positivity [31]. In the case of diffuse mark, staining intensity was evaluated with an automated digitizing system (UN-SCAN-IT gel 4.1, Silk Scientific Co, USA) and the data were expressed as number of pixels.

Immunohistochemical detection of endothelial cell marker PECAM-1 in denervated ovaries was performed using an antibody from Santa Cruz Biotechnology (antiPECAM-1 [M-20] in a 1:100 dilution). Tissue sections were incubated with the antibody overnight at $4{ }^{\circ} \mathrm{C}$ and the immunoreaction was developed the next day using the DAB procedure (LabVision Co, Freemont CA, USA). Controls consisted of adjacent sections incubated without the primary antibody. The area of positive staining was evaluated with an automated system (Image J 1.36b, NIH, USA) and the data were expressed as \% area of the ovary section.

\section{RNA extraction and reverse transcription reaction}

Total RNA was extracted from rat ovaries using guanidine isothiocyanate and phenol-chloroform extraction (Trizol Reagent, Invitrogen, Foster City CA, USA) following the manufacturer's protocol. Concentration and purity of RNA were measured using a spectrophotometer at 260 and $280 \mathrm{~nm}$. First strand cDNA was synthesized in a $20 \mathrm{ml}$ reaction mixture using $1 \mu \mathrm{g}$ of total RNA. The reaction tubes contained $0.5 \mu \mathrm{l}$ random hexamers $(500 \mathrm{ng} / \mu \mathrm{l}$, Invitrogen, Foster City CA, USA), $1 \mu \mathrm{l}$ dNTPs (10 mM, Invitrogen, Foster City CA, USA), $4 \mu \mathrm{l} 5 \times$ reaction buffer $(250$ $\mathrm{mM}$ Tris-HCl pH 8.3, $375 \mathrm{mM} \mathrm{KCl}, 15 \mathrm{mM} \mathrm{MgCl}$ 2, Invitrogen, Foster City CA, USA), $2 \mu$ l DTT (0.1 M, Invitrogen, Foster City CA, USA), $1 \mu \mathrm{l}$ ribonuclease inhibitor (10 U/ $\mu \mathrm{l}$, Invitrogen, Foster City CA, USA) and $1 \mu \mathrm{l}$ M-MLV reverse transcriptase $(200 \mathrm{U} / \mu \mathrm{l}$, Invitrogen, Foster City CA, USA). Reactions were incubated at $37^{\circ} \mathrm{C}$ for $60 \mathrm{~min}-$ utes and inactivated by freezing.

\section{Polymerase chain reaction}

The specific primer sequences for the examined genes and the predicted PCR product sizes are shown in Table 1. The cDNA was amplified in a $25 \mu \mathrm{l}$ reaction mixture using $1 \mu \mathrm{l}$ of single-strand cDNA. PCR conditions were as follows: $2.5 \mu \mathrm{l} 10 \times$ reaction buffer (200 mM Tris-HCl pH 8.4, 500 $\mathrm{mM} \mathrm{KCl}$, Biotools, Madrid, Spain), $1 \mu \mathrm{l} \mathrm{MgCl} 2(50 \mathrm{mM})$, $0.5 \mu \mathrm{l}$ dNTPs (10 mM each), $1.25 \mu \mathrm{l}$ each primer $(10 \mu \mathrm{M}$, Polyscience, Santiago, Chile), $0.15 \mu$ l DNA polymerase (5 $\mathrm{U} / \mu \mathrm{l}$, Biotools, Madrid, Spain). Reaction mixtures were incubated in a thermal cycler (Eppendorf, Foster City CA, USA) for 2 minutes at $94^{\circ} \mathrm{C}$. Then 23,27 , or 28 cycles were performed for cyclophilin, VEGF and TGF $\beta 1$ respectively including: denaturation at $94^{\circ} \mathrm{C}$ for 45 seconds, annealing at $62^{\circ} \mathrm{C}$ for 1 minute and extension at $72^{\circ} \mathrm{C}$ for 1 minute. The optimal number of cycles was experimentally determined by analyzing the exponential phase of amplification reaction (data not shown). The PCR products were separated on Tris-borate-EDTA 2\% agarose gels containing $200 \mathrm{ng} / \mathrm{ml}$ ethidium bromide (Invitrogen, Foster City CA, USA). DNA size markers were run in parallel to validate the predicted sizes of the amplified bands (100-bp DNA ladder, Biotools, Madrid, Spain). The gels were visualized under UV light, photographed using a capturing program (Ultra Violet Products Doc-It), and analyzed with an automated digitizing system (UNSCAN-IT gel 4.1, Silk Scientific Corporation, Orem UT, USA). Differences between the experimental versus control conditions, were obtained by the ratio of the intensity between specific gene and constitutive gene of each sample, determined by densitometry.

\section{Statistical analysis}

The differences in mRNA levels, immunoreactivity and area of positive staining were analyzed using Mann Whitney test.

\section{Results \\ NGF increases VEGF mRNA and protein levels in neonatal rat ovaries}

The photograph of $2 \%$ agarose gel electrophoresis of representative PCR products for VEGF120, VEGF164, TGFß1 and Cyclophilin (as constitutive gene) are shown in figure 
Table I: Primer sequences used for PCR of CDNAs

\begin{tabular}{clcc}
\hline Gene & \multicolumn{1}{c}{ Forward and reverse primers $\left(5^{\prime}-3^{\prime}\right)$} & PCR product size (bp) & Reference \\
\hline \multirow{2}{*}{ VEGF } & F: GCCAGCACATAGGAGAGATGAG & 234,102 & Adapted from [45] \\
& R: ACCGCCTTGGCTTGTCAC & 246 & {$[46]$} \\
TGF $\beta$ I & F: AAGTGGATCCACGAGCCCAA & & 350 \\
Cyclophilin & R: GCTGCACTTGCAGGAGCGCA & CTTTGCAGACGCCGCTGTCTCTTTTCGCCG & \\
& R: GCATTTGCCATGGACAAGATGCCAGGA & $47]$ \\
\hline
\end{tabular}

1A-C. The exponential phase of amplification for each target sequence was determined by performing PCR under different number of cycles (ranging from 20 to 35 cycles). The PCR products were separated in agarose gels, stained with ethidium bromide, and the intensity of the bands was analyzed with an automated digitalizing program (UN-SCAN-IT gel 4.1, Silk Scientific Corporation, Orem UT, USA). Results were plotted to visualize the exponential region of the curve, and thus the optimal number of cycles was selected for each target sequence (not shown). A dose/response curve was performed for each target sequence by adding increasing amounts of cDNA to the respective PCR mix. The response showed to be linear under working conditions (see figure 1D-F).

Neonatal rat ovaries were cultured with NGF $(100 \mathrm{ng} / \mathrm{ml})$ for 2, 4, 8 and $24 \mathrm{~h}$. The mRNA levels for VEGF 120 and VEGF 164 - the most relevant VEGF isoforms in ovarian physiology - exhibited a significant increase in NGF-stimulated tissues compared to controls, in the two-hour culture, as shown in figure 2 . No change on TGF $\beta 1$ mRNA content was found at any assayed stimulation time.

Regarding localization of VEGF protein in neonatal rat ovaries, although two controls for specificity were used, immunoreactivity was present more specifically in granulosa cell layer of primary follicles (figures $3 \mathrm{~A}$ and $3 \mathrm{~B}$ ) and also in other types of ovarian cells (figures 3C and 3D). Densitometric analysis of the immune signal revealed that after 24 hour incubation, NGF induced an increase in VEGF staining in neonatal rat ovaries, which was significant both for the overall staining of the ovarian tissue and for staining of primary follicles (figure 3F). No significant differences in VEGF staining were found in shorter incubations $(2,4$ or $8 \mathrm{~h})$. As to TGF $\beta 1$, a specific mark was detected in oocytes (figure $4 \mathrm{~A}$ and $4 \mathrm{~B}$ ). The same as for mRNA, H-Score of TGF $\beta 1$ immunoreactivity was not modified by NGF (figure 4D).

\section{Denervation of the ovary increases VEGF immunoreactivity in prepubertal rats}

It was important to determine whether this neurotrophin would increase VEGF in an in vivo condition previously informed to provoke an increase in NGF in the rat ovary. We performed a superior ovarian nerve (SON) sectioning in prepubertal rats and confirmed that NGF protein levels, evaluated by densitometry of immunohistochemistryprocessed tissues, were increased in theca cell layers of ovaries obtained from denervated animals when compared to control ones (figure 5). Nevertheless, after 6 days of denervation, no change was found in mRNA level of VEGF and TGF $\beta 1$ (figure 6). Although there were no differences in mRNA content, H-Score evaluation indicated that the immunoreactivity for VEGF was significantly increased in the inner granulosa cell layer of denervated ovaries as compared with control animals (Figure 7A,B and 7D). TGF $\beta 1$ immunoreactivity did not change after denervation (results not shown). To evaluate if there was an earlier change in VEGF and TGF $\beta 1$ mRNA levels or in TGF $\beta 1$ protein, the same studies were performed on day 3 of SON sectioning. We found no significant difference for any of the markers studied (results not shown).

\section{Denervation of the ovary increases blood vessels area in prepubertal rats}

We wanted to evaluate if denervated rats, which have higher ovarian NGF levels, present an increase in ovarian blood vessels. Immunohistochemical studies revealed that the amount of ovarian small vessels and capillaries, evaluated as \% area of PECAM- 1 positive staining was increased in rats denervated for 6 days, when compared to control animals (figure 8A-D and 8G). A similar result was found in denervated animals as early as three days after SON sectioning (figure $8 \mathrm{~F}$ ).

\section{Discussion}

The present study shows that NGF increased the expression of the angiogenic factor VEGF and the area of blood vessels detected by the endothelial cell marker PECAM-1, making a connection between two essential processes in ovarian physiology, such as angiogenesis and ovulation.

There is an increase of both NGF and its receptor trkA a few hours before ovulation in the rat ovary; this seems to be a critical step in the ovulatory cascade, since the use of a neutralizing antibody to NGF or a blocker of trkA activity inhibits the ovulation [19]. In this periovulatory time and specially following ovulatory rupture, there is period of intensive follicular/luteal vascularization, in which angiogenic growth factors such as VEGF, essential for 
A

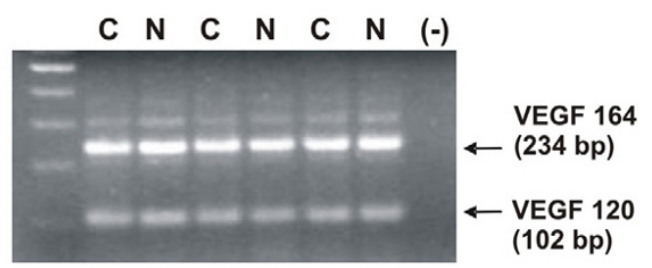

B

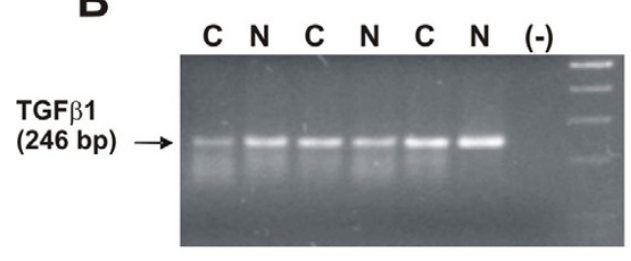

C

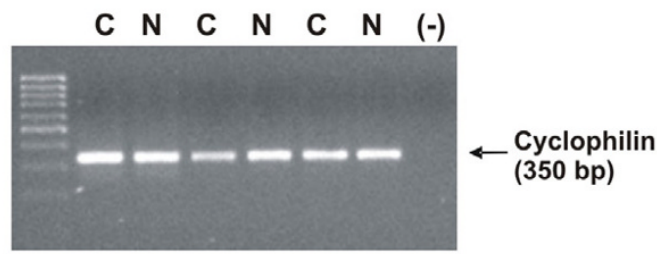

D

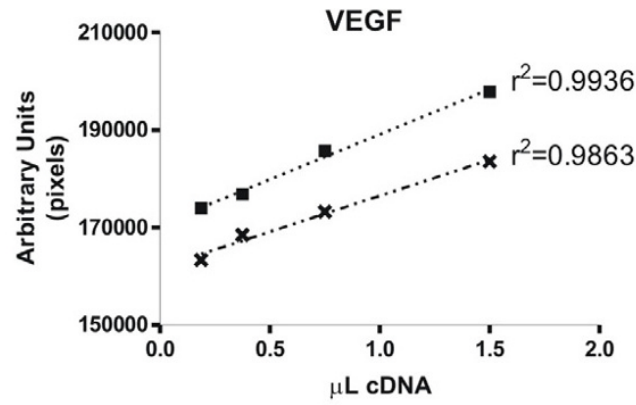

E
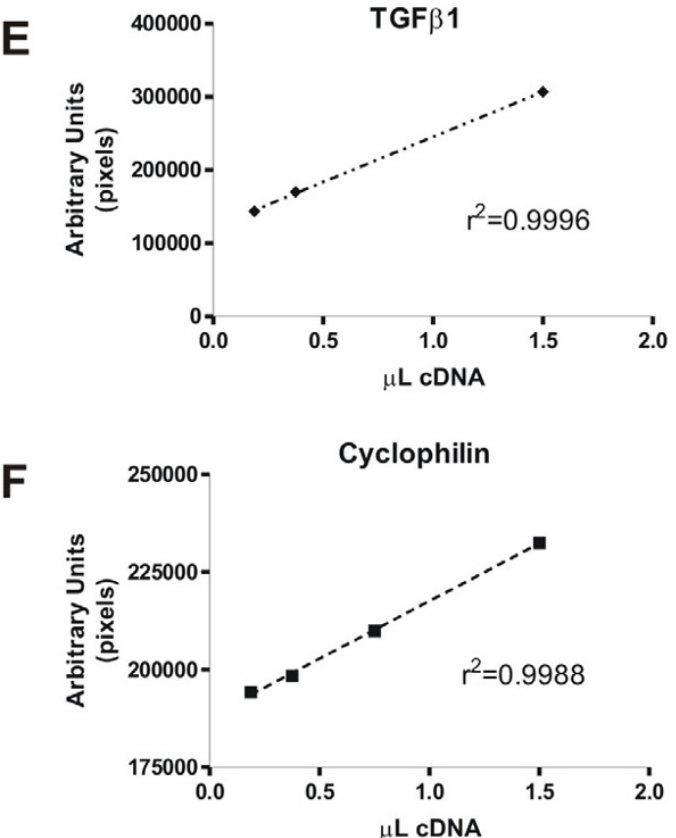

\section{Figure I}

PCR products for the cDNAs evaluated in this study. Pannels $A, B$ and $C$ show photographs of agarose electrophoresis for representative PCR products of the different target sequences studied: Pannel A shows PCR products for VEGF ( 102 bp for VEGF 120 and 234 bp for VEGF 164) of control samples (C) and NGF treated ovaries (N); additional bands corresponding to other VEGF isoforms were also visible for some samples and thus could not be considered in this study. Pannel $B$ shows PCR product for TGF $\beta$ I (246 bP) of control (C) and NGF treatment (N); Pannel C shows PCR products for the constitutive gene Cyclophilin (350 bp) of control (C) and NGF treatment (N). Negative controls in each photograph correspond to the lane indicated as (-). Pannels D, E and F represent graphs of PCR reactions starting with different quantities of $C D N A$, indicating the linear range in which each densitometry was made in order to observe differences in each experimental condition: D) Linear range for VEGF amplification ( $r^{2}=0.9936$ for VEGF 120 and $r^{2}=0.9863$ for VEGF I64); E) Linear range for TGF 3 I amplification $\left(r^{2}=0.9996\right)$; F) Linear range for Cyclophilin amplification $\left(r^{2}=0.9988\right)$. Each graph represents PCR products obtained from a pool of cDNA samples.

endothelial cell proliferation, become highly expressed $[1,7]$.

Finding VEGF expression in the neonatal ovary suggests that VEGF could also have actions different from neovascularization in early stages of ovarian development (e.g. proliferation of somatic cells or increased vessel permeability to allow extravasation of nutrients and hormones).
NGF induced an early VEGF mRNA increase in neonatal rat ovaries. The explanation of this rapid response could lie on the presence of trkA in the rat ovary shortly after birth [32]. Indeed, NGF has been found necessary not only during the ovulatory process: ovaries from NGF-null mutant mice have a reduced population of primary and secondary follicles, a higher number of oocytes that are not incorporated into follicles, and a reduction in cell pro- 


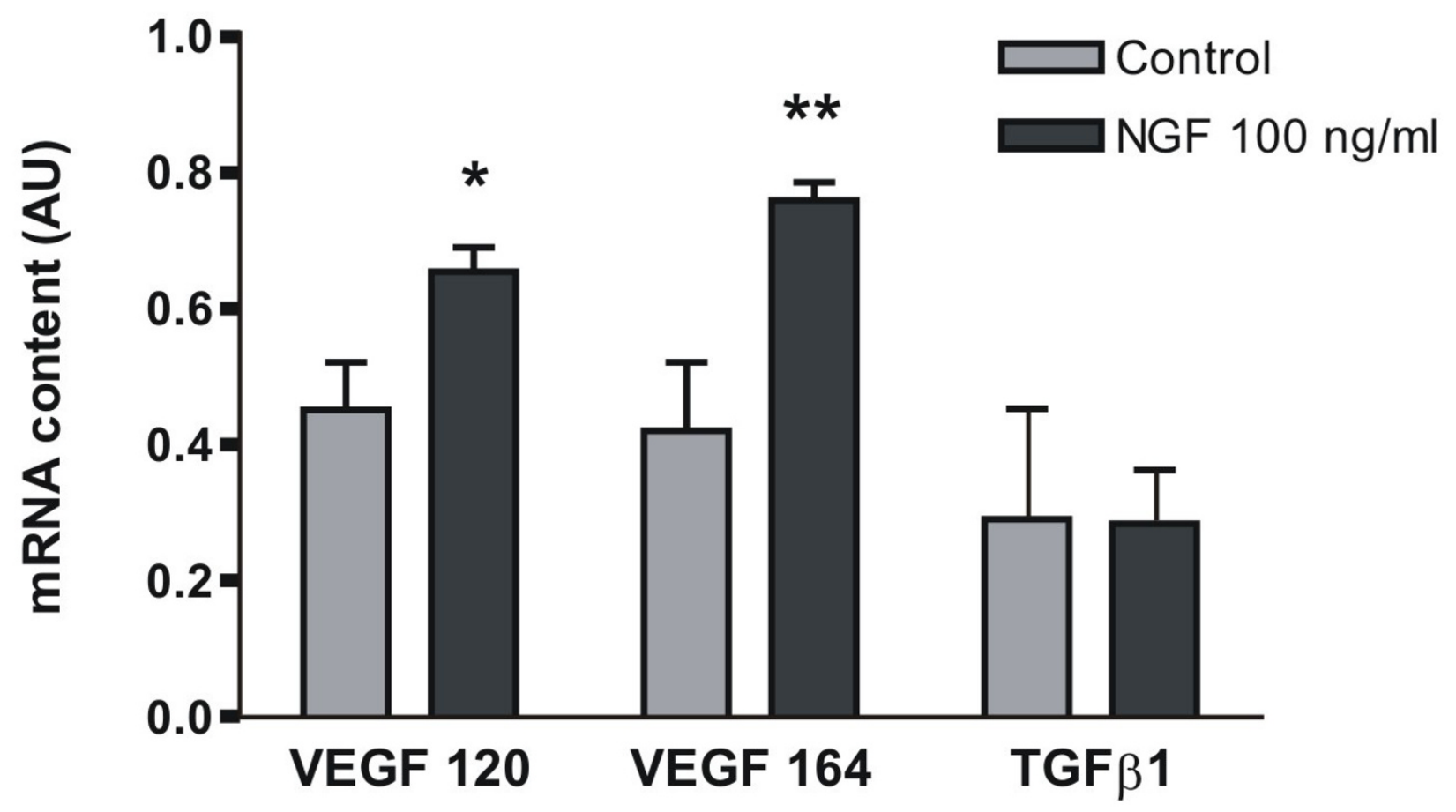

Figure 2

mRNA content of VEGF isoforms and TGF $\beta$ I in neonatal rat ovaries cultured for 2 hours with NGF. The results were evaluated by densitometric analysis of PCR products bands and expressed as arbitrary units (AU, pixels from specific gene/pixels from constitutive gene) mean \pm SEM from $n=5$. $* p<0.05$ and $* * p<0.0$ I vs control.

liferation. [33]. Immunoneutralization of NGF during early postnatal life of the rat impairs the growth of antral follicles and delays puberty [18]. In this respect, the NGF/ trkA complex may act as a regulator of ovarian VEGF expression in the first days of postnatal life of the rat.

This study shows that NGF can increase two mayor angiogenesis-related parameters within the ovary: 1) the expression of VEGF, an ovarian pro-angiogenic molecule, and 2) the amount of ovarian blood vessels. It remains to be elucidated if the increase in blood vessels is a consequence of NGF binding to trkA receptor in endothelial cells, or is mediated by the increase of VEGF, but it is reported that NGF is able to activate endothelial cell proliferation independent of VEGF [34]. VEGF 120 and VEGF 164 mRNAs did not change after three or six days of SON denervation, a result that could be explained by the early response of neonatal ovaries exposed to NGF.

NGF did not modify TGF $\beta 1$ expression, either in neonatal or in prepubertal rat ovaries. This, in addition to previously informed data in the hamster ovary that the expression of TGF $\beta$ receptors mRNA changed cyclically [13], suggest that TGF $\beta 1$ action on ovarian cycle might be con- trolled at TGF $\beta$ receptor expression rather than ligand level. On the other hand, it is known that NGF is able to modulate the expression of TGF $\beta$ receptors in grafted adrenal chromaffin cells, by reducing the level of T $\beta$ RII mRNA [35]. Then, it would be very interesting to study the NGF effect on TGF $\beta$ receptors expression in the ovary to better understand this mechanism.

Defects in angiogenesis regulation can be related with a variety of pathologies, like hemangioma, psoriasis and most of neoplasic conditions [36-38]. Women suffering from polycystic ovaries have an increased ovarian blood flow, which is probably associated with the higher serum VEGF levels found in these patients [39]. An elevation of ovarian NGF and p75 is observed in rats with steroidinduced polycystic ovaries, and the intraovarian administration of a neutralizing antiserum to NGF in conjunction with an antisense to p75 normalized estrous cyclicity and ovulatory capacity in a majority of the animals [40]. It cannot be discarded that fertility disorders like polycystic ovary, or others associated with impaired angiogenesis have a genesis in a deregulation of NGF expression or function that results in aberrant production of VEGF. 
Control

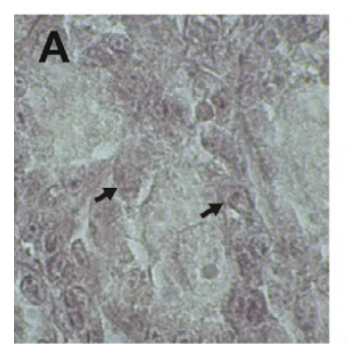

NGF

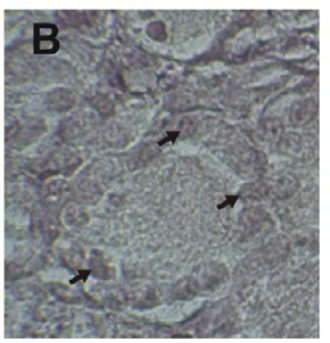

Control

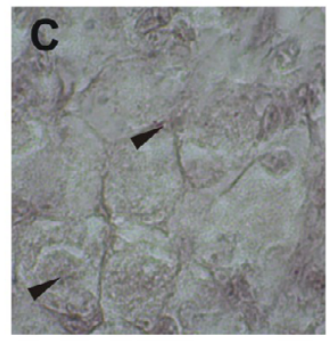

NGF

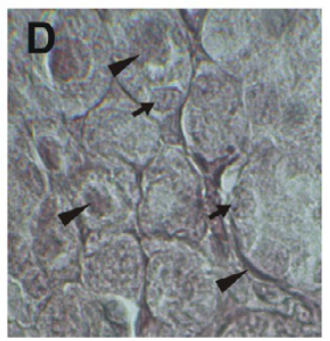

$\operatorname{IHC}(-)$

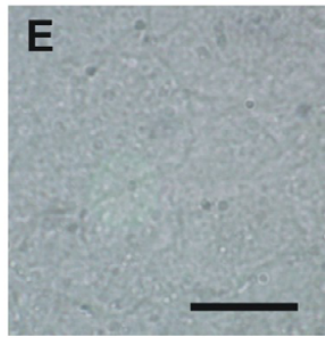

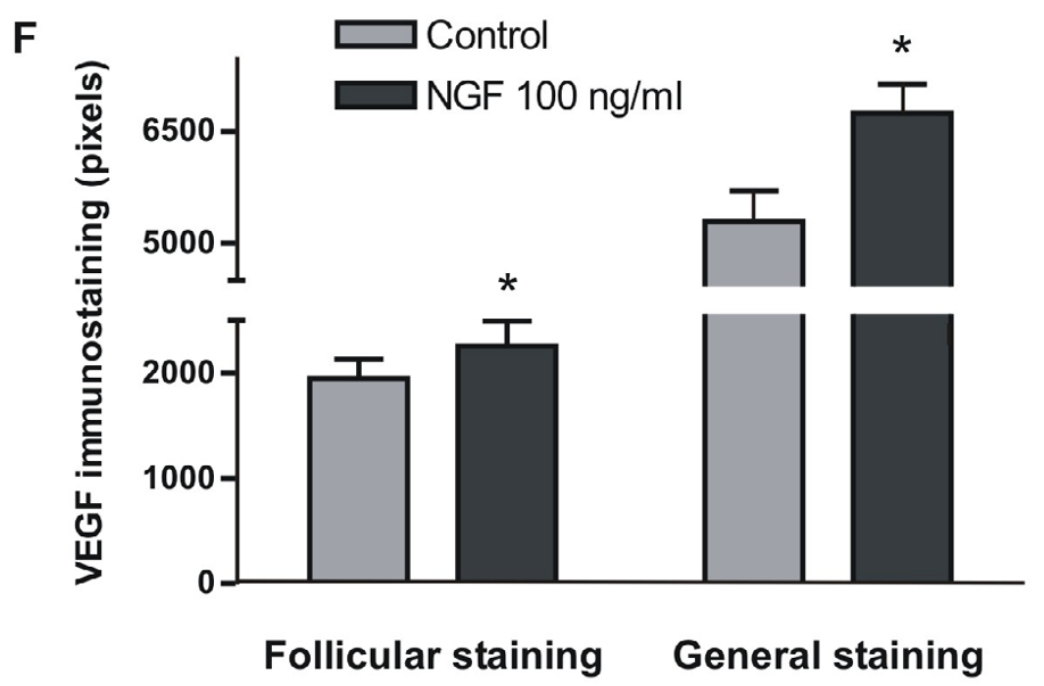

Figure 3

VEGF immunostaining in neonatal rat ovaries cultured for 24 hours with NGF. Arrows depict the predominant location of VEGF in granulosa cells of the ovarian follicles (A-B). Arrowheads indicate the presence of VEGF in other cell types of the tissue (C-D), such as oocytes. $A$ and $C$ show the staining of representative control ovaries, and $B$ and $D$ the respective NGF-treated tissues. A negative immunohistochemistry is shown in E. Mean \pm SEM for densitometry from $n=5$, are shown in F. $* \mathrm{p}<0.05$ vs control. Original magnification 100x. Bar $=50 \mu \mathrm{m}$.
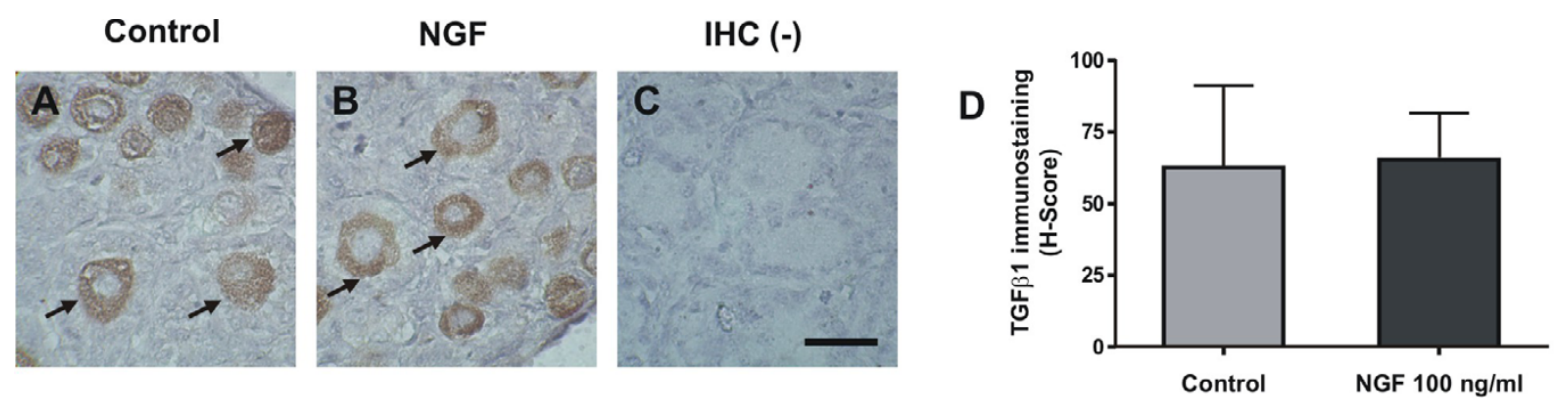

\section{Figure 4}

TGF $\beta$ I immunostaining in neonatal rat ovaries cultured for 24 hours with NGF. Arrows depict the predominant location of TGF $\beta$ I at the oocytes. A and B show the staining of control and NGF-treated ovaries, respectively. A negative immunohistochemistry is shown in C. Mean \pm SEM for $\mathrm{H}$-Score from $n=5$ are shown in D. Original magnification 100x. Bar $=$ $50 \mu \mathrm{m}$. 


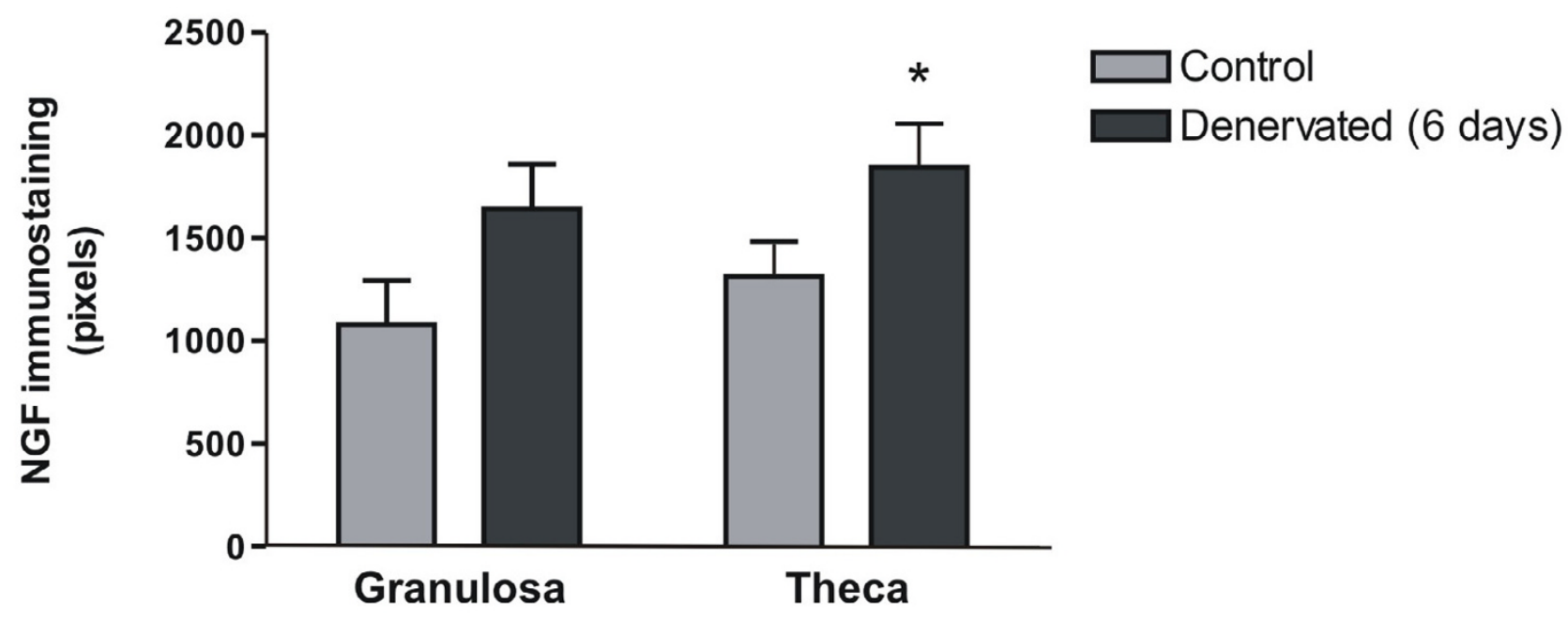

Figure 5

NGF immunostaining in rats with a dissection of the superior ovarian nerve (SON). Positive reaction was evaluated by densitometry and results were expressed as mean \pm SEM from $n=5$. $* p<0.05$ vs control.

Finally, our group has demonstrated that VEGF is regulated by NGF in epithelial ovarian cancer [41].
Accumulating evidence about the importance of the neurotrophins and their receptors in ovarian physiology has

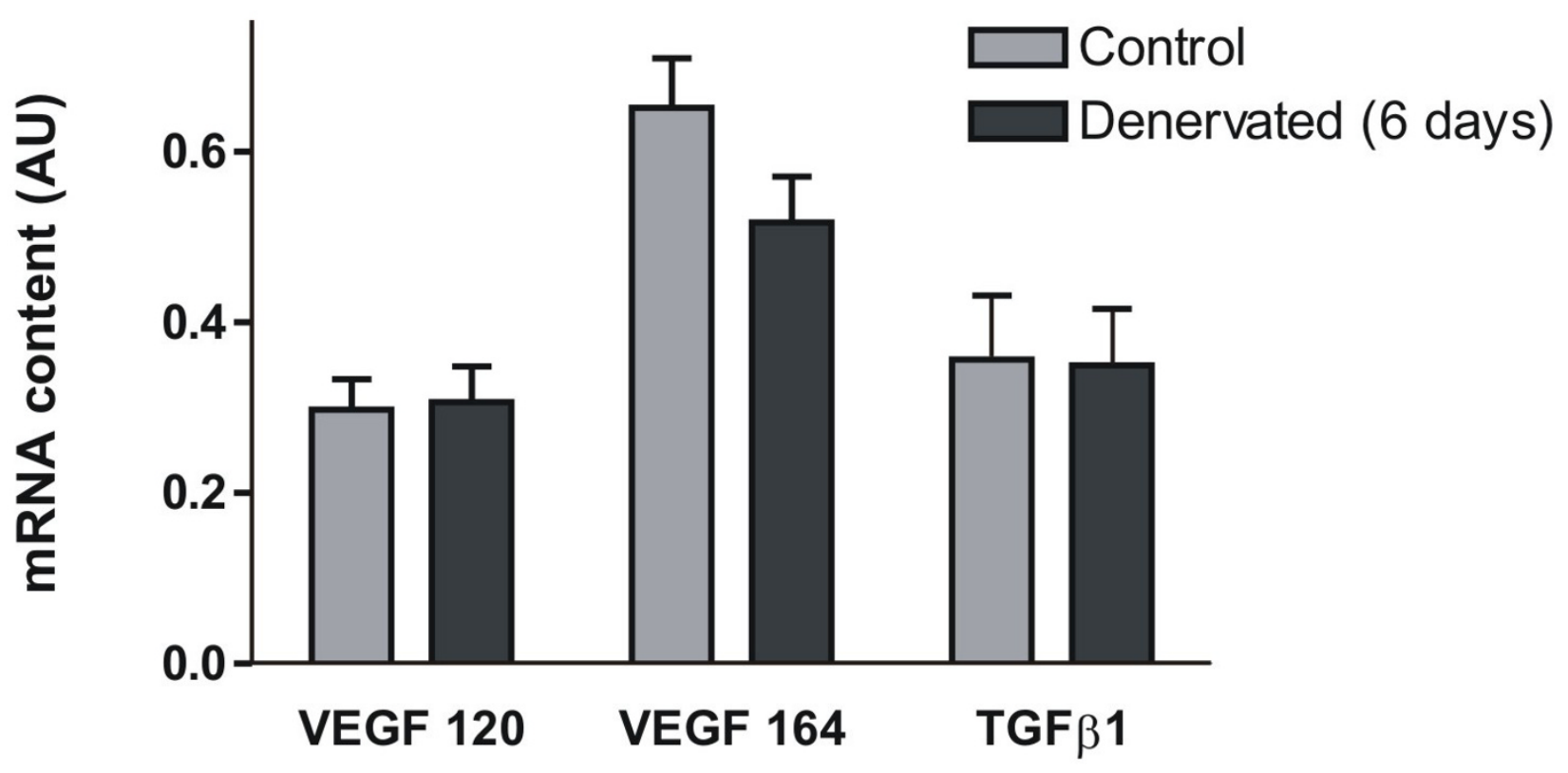

Figure 6

mRNA content of VEGF isoforms and TGF $\beta I$ in rats with increased ovarian NGF induced by SON dissection. The results were evaluated by densitometric analysis of PCR products bands and expressed as arbitrary units (AU, pixels from specific gene/pixels from constitutive gene) mean \pm SEM from $n=5$. 


\section{Control}

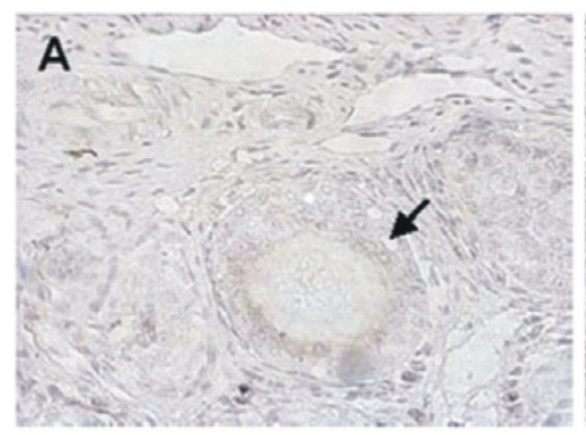

Denervated

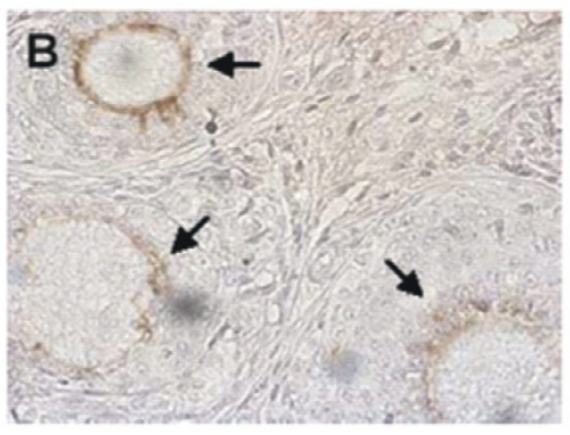

IHC (-)

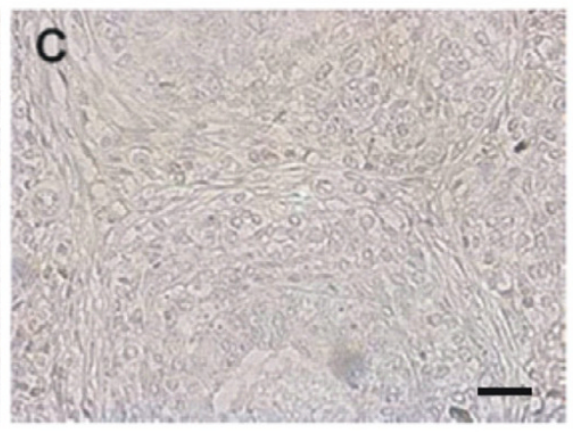

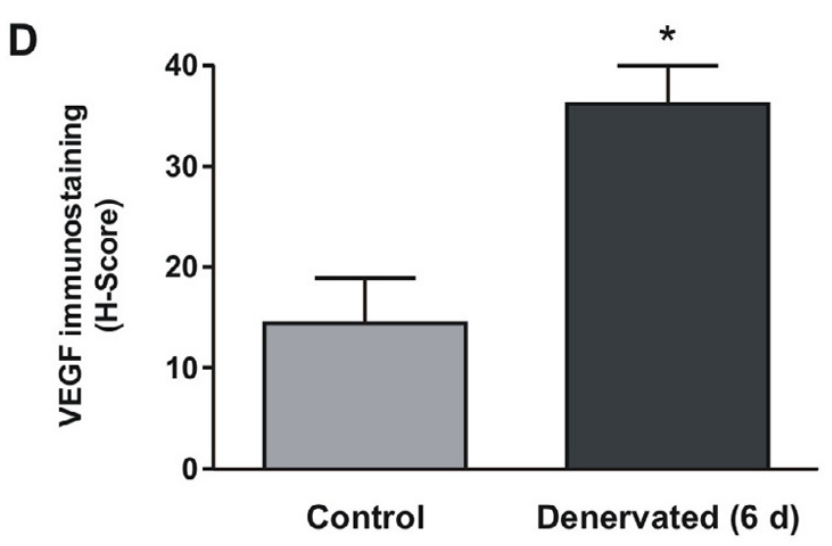

\section{Figure 7}

VEGF immunostaining in rats with increased ovarian NGF as a consequence of SON dissection. The predominant location of VEGF was the inner layer of the granulosa compartment, as depicted by arrows. A and B show the staining of control and denervated ovaries, respectively. Negative control is shown in C. Mean \pm SEM for $\mathrm{H}$-Score from $n=3$, are shown in $\mathrm{D}$. * $\mathrm{p}<0.05$ vs control. Original magnification $40 \times$. Bar $=150 \mu \mathrm{m}$.

appeared [14-16]. In addition to NGF, also BDNF, NT3 and NT4 have been described in the neonatal ovary $[32,42]$ and some of them have been associated with early follicular development [32]. NGF and trkA have been involved in processes such as steroidogenesis, FSH receptor expression and proliferation of somatic cells in rodent and human ovary $[17,43,44]$. Our results are the first to relate NGF with ovarian angiogenesis and confirm the angiogenic effects of NGF in the rat ovary, giving new insight for a role of NGF in the mammalian ovarian function.

\section{Conclusion}

PCR and immunohistochemistry studies showed that NGF can increase VEGF expression in cultured neonatal rat ovaries. This was verified in an in vivo model: prepubertal rats with a dissection of the superior ovarian nerve performed to increase the local levels of NGF - had also increased VEGF immunoreactivity within the ovary on the day six after denervation. TGF $\beta 1$ expression was not modified by NGF in any of the models under study.

In prepubertal rats NGF is able to increase the area of ovarian vessels, as shown by endothelial cell staining. The \% area of PECAM-1 positive staining was increased in rats denervated for 3 and 6 days, when compared to control animals.

In summary, the present study shows that NGF increases the expression of the angiogenic factor VEGF and the area of blood vessels in the rat ovary, two major events of the periovulatory period that are fundamental for ovarian physiology.

\section{Competing interests}

The author(s) declare that they have no competing interests. 


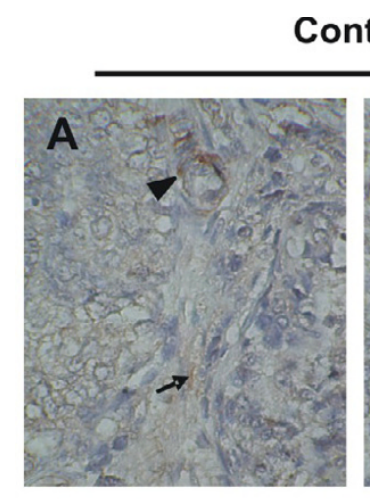

Control
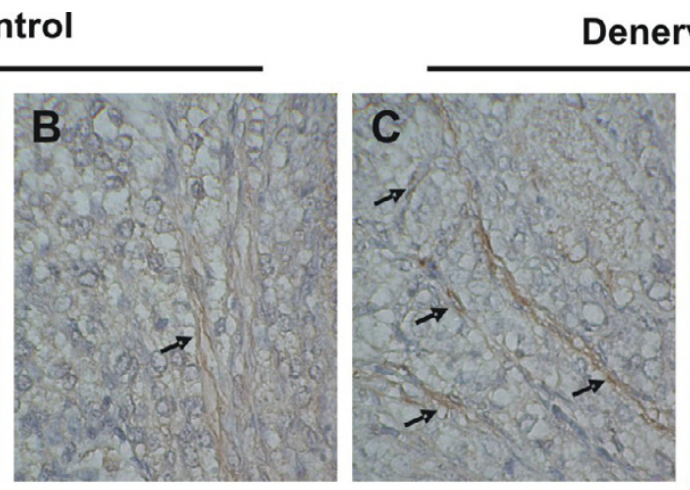

Denervated

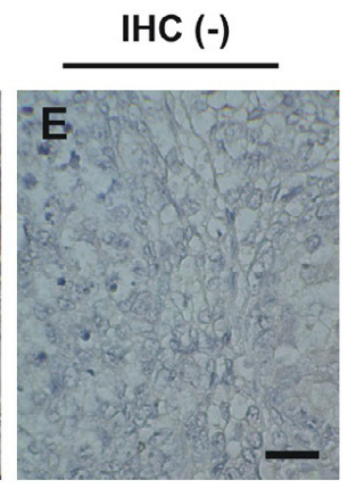

$\mathbf{F}$

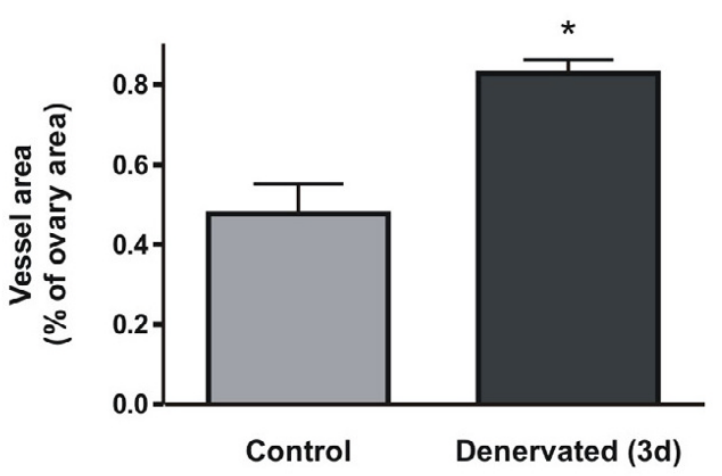

G

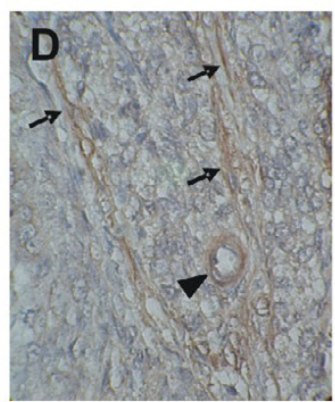

Small vessels and capillaries area

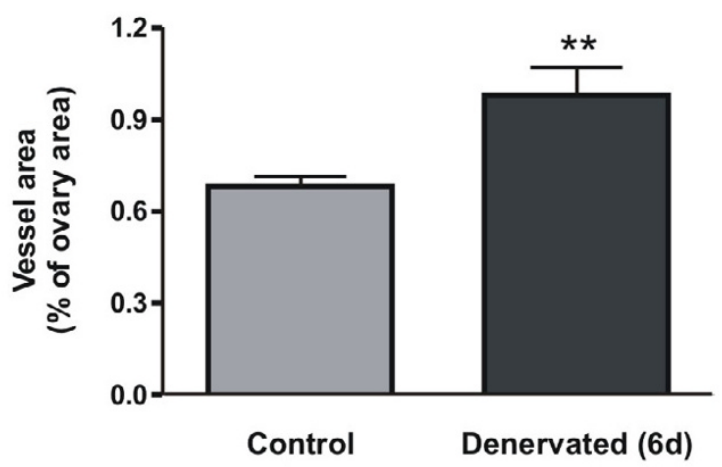

Figure 8

PECAM-I immunostaining in rats with increased ovarian NGF as a consequence of SON dissection. Arrows depict the predominant location of vessels in the area surrounding the ovarian follicles. Small vessels are depicted by arrowheads. A-B show the immunostaining found in control rat ovaries, and C-D show the ovaries of 6-day denervated rats, where a bigger area of capillaries and small vessels was stained. $F$ and $G$ show the quantification of the stained vessels area in rats denervated for $3(n=3)$ and 6 days $(n=5)$, respectively. The area of vessels positively stained was evaluated with the Image-J program and results were expressed as mean \pm SEM. ${ }^{*} p<0.05$ and ${ }^{* *} p<0.01$ vs control. Original magnification I00x. Bar $=100$ $\mu \mathrm{m}$.

\section{Authors' contributions}

MJ-P carried out the experimental design, performed the tissue cultures, immunohistochemistries and PCR studies, statistical analysis, interpretation of data and drafted the manuscript. HEL performed the rat surgeries and contributed to draft the manuscript. JAB helped with the rat surgeries and contributed to the data analysis and to draft the manuscript. CR participated in the design and coordination of the study, contributed to the data analysis and helped to draft the manuscript. All authors read and approved the final manuscript.

\section{Acknowledgements}

We thank Dr. Ximena Campos for critical comments and Prof. Claudio Telha for manuscript reviewing. This research was supported by grants Fondo Nacional de Desarrollo Científico y Tecnológico \#I03066 I (CR), Comisión Nacional de Investigación Científica y Tecnológica \#4040059 and Departamento de Postgrado y Postítulo Universidad de Chile \#PG/90/2003 and \#PG/67/2005 (MJ-P). MJ-P and JAB are PhD students of the Biochemistry Postgraduate Program of Universidad de Chile, supported by scholarships from the Comisión Nacional de Investigación Científica y Tecnológica (Conicyt \#10224I and 102240, respectively).

\section{References}

I. Fraser HM, Wulff C: Angiogenesis in the primate ovary. Reprod Fertil Dev 200I, 13:557-566.

2. Mattioli M, Barboni B, Turriani M, Galeati G, Zannoni A, Castellani G, Berardinelli, Scapolo PE: Follicle activation involves vascular endothelial growth factor production and increased blood vessel extension. Biol Reprod 2001, 65:1014-1019.

3. Ferrara N: Role of vascular endothelial growth factor in regulation of physiological angiogenesis. Am J Physiol Cell Physiol 200I, 280: CI358-CI366.

4. Wulff C, Wilson H, Wiegand SJ, Rudge JS, Fraser HM: Prevention of thecal angiogenesis, antral follicular growth, and ovulation in the primate by treatment with vascular endothelial growth factor trap RIR2. Endocrinology 2002, 143:2797-2807.

5. Geva E, Jaffe RB: Role of vascular endothelial growth factor in ovarian physiology and pathology. Fertil Steril 2000, 74:429-438. 
6. Philips HS, Hains J, Leung DW, Ferrara N: Vascular endothelial growth factor is expressed in rat corpus luteum. Endocrinology 1990, I 27:965-967.

7. Koos RD: Increased expression of vascular endothelial growth/permeability factor in the rat ovary following an ovulatory gonadotropins stimulus. Biol Reprod 1995, 52:|426-|435.

8. Pepper MS: Transforming growth factor-beta: vasculogenesis, angiogenesis, and vessel wall integrity. Cytokine Growth Factor Rev 1997, 8:21-43.

9. Papetti M, Herman IM: Mechanisms of normal and tumorderived angiogenesis. Am J Physiol Cell Physiol 2002, 282:C947-C970.

10. Chegini N, Flanders KC: Presence of transforming growth factor- $\beta$ and their selective cellular localization in human ovarian tissue of various reproductive stages. Endocrinology 1992, I30:|707-17|5.

II. Chegini N, Williams RS: Immunocytochemical localization of transforming growth factors (TGFs) TGF- $\alpha$ and TGF- $\beta$ in human ovarian tissues. J Clin Endocrinol Metab 1992, 74:973-980.

12. Findlay JK, Drummond AE, Dyson ML, Baillie AJ, Robertson DM, Ethier JF: Recruitment and development of the follicle; the roles of the transforming growth factor- $\beta$ superfamily. Mol Cell Endocrinol 2002, 1 9 1:35-43.

13. Roy SK: Regulation of transforming growth factor- $\beta$-receptor type I and type II messenger ribonucleic acid expression in the hamster ovary by gonadotropins and steroid hormones. Biol Reprod 2000, 62:1858-1865.

14. Mattioli M, Barboni B, Gioia L, Lucidi P: Nerve growth factor production in sheep antral follicles. Domest Anim Endocrinol 1999, | 7:36|-37|.

15. Ren L, Medan MS, Weng Q, Jin W, Li C, Watanabe G, Taya K: Immunolocalization of nerve growth factor (NGF) and its receptors (trkA and p75LNGFR) in the reproductive organs of Shiba goats. J Reprod Dev 2005, 5 I:399-404.

16. Levanti MB, Germana A, Abbate F, Montalbano G, Vega JA, Germana G: TrkA and p75NTR in the ovary of adult cow and pig. J Anat 2005, 207:93-96.

17. Romero C, Paredes A, Dissen GA, Ojeda SR: Nerve growth factor induces the expression of functional FSH receptors in newly formed follicles of the rat ovary. Endocrinology 2002, | 43: | 485- | 494 .

18. Lara HE, McDonald JK, Ojeda SR: Involvement of nerve growth factor in female sexual development. Endocrinology 1990, I 26:364-375.

19. Dissen GA, Hill DF, Costa ME, Les Dees CW, Lara HE, Ojeda SR: A role for trkA nerve growth factor receptors in mammalian ovulation. Endocrinology 1996, 137:198-209.

20. Chiaretti A, Piastra M, Caresta E, Nanni L, Aloe L: Improving ischaemic skin revascularisation by nerve growth factor in a child with crush syndrome. Arch Dis Child 2002, 87:446-448.

21. Emanueli C, Salis MB, Pinna A, Graiani G, Manni L, Madeddu P: Nerve growth factor promotes angiogenesis and arteriogenesis in ischemic hindlimbs. Circulation 2002, 106:2257-2262.

22. Seo K, Choi J, Park M, Rhee C: Angiogenesis effects of nerve growth factor (NGF) on rat corneas. J Vet Sci 200 I, 2: I 25- I 30

23. Manni L, Antonelli A, Costa N, Aloe L: Stress alters vascular endothelial growth factor expression in rat arteries: Role of nerve growth factor. Basic Res Cardiol 2005, I 00: I 2 I- I 30.

24. Wang T, Horng S, Chang C, Wu H, Tsai Y, Wang H, Soong $Y$ : Human chorionic gonadotropin-induced ovarian hyperstimulation syndrome is associated with up-regulation of vascular endothelial growth factor. J Clin Endocrinol Metab 2002, 87:3300-3308.

25. Laitinen M, Ristimäki A, Honkasalo M, Narko K, Paavonen K, Ritvos $\mathrm{O}$ : Differential hormonal regulation of vascular endothelial growth factors VEGF, VEGF-B, and VEGF-C messenger ribonucleic acid levels in cultured human granulosa-luteal cells. Endocrinology 1997, I 38:4748-4756.

26. Dissen GA, Lara HE, Fahrenbach WH, Costa ME, Ojeda SR: Immature rat ovaries become revascularized rapidly after autotransplantation and show a gonadotropin-dependent increase in angiogenic factor gene expression. Endocrinology 1994, I34: I| 146-II54.

27. McGee EA, Hsueh AW: Initial and cyclic recruitment of ovarian follicles. Endocrine Rev 2000, 2 I:200-2 I4.
28. George FW, Ojeda SR: Vasoactive intestinal peptide enhances aromatase activity in the neonatal rat ovary before development of primary follicles or responsiveness to follicle-stimulating hormone. Proc Natl Acad Sci USA 1987, 84:5803-5807.

29. Lara HE, Hill DF, Katz KH, Ojeda SR: The gene encoding nerve growth factor is expressed in the immature rat ovary: effect of denervation and hormonal treatment. Endocrinology 1990, I 26:357-363.

30. Gerendai I, Marchetti B, Maugeri S, Roxas MA, Scapagnini U: Prevention of compensatory ovarian hypertrophy by local treatment of the ovary with 6-OHDA. Neuroendocrinology 1978, 27:272-278.

31. Anaf V, Simon P, El Nakadi I, Fayt I, Simonart T, Buxant F, Noel JC: Hyperalgesia, nerve infiltration and nerve growth factor expression in deep adenomyotic nodules, peritoneal and ovarian endometriosis. Hum Reprod 2002, I 7:1895-1900.

32. Dissen GA, Hirshfield AN, Malamed S, Ojeda SR: Expression of Neurotrophins and their receptors in the mammalian ovary is developmentally regulated: changes at the time of folliculogenesis. Endocrinology 1995, I36:468|-4692.

33. Dissen GA, Romero C, Newman Hirshfield A, Ojeda SR: Nerve growth factor is required for early follicular development in the mammalian ovary. Endocrinology 200I, I 42:2078-2086.

34. Cantarella G, Lempereur L, Presta M Ribatti R, Lombardo G, Lazarovici $P$, Zappala $G$, Pafumi $C$, Bernardini R: Nerve growth factorendothelial cell interaction leads to angiogenesis in vitro and in vivo. FASEB J 2002, 16:1307-1309.

35. Förander P, Krieglstein K, Söderström S, Strömberg I: Mutual induction of TGF $\beta I$ and NGF after treatment with NGF or TGF $\beta I$ in grafted chromaffin cells of the adrenal medulla. Exp Neurol 2000, I 64:303-3 I3.

36. Yu Y, Flint AF, Mulliken JB, Wu JK, Bischoff J: Endothelial progenitor cells in infantile hemangioma. Blood 2004, I 03:1373-I375.

37. Veale DJ, Ritchlin C, FitzGerald O: Immunopathology of psoriasis and psoriatic arthritis. Ann Rheum Dis 2005, 64:26-29.

38. Ferrara N, Davys-Smith T: The biology of vascular endothelial growth factor. Endocrine Rev 1997, 1 8:4-25.

39. Agrawal R, Sladkevicius P, Engmann L, Conway GS, Payne NN, Bekis J, Tan SL, Campbell S, Jacobs HS: Serum vascular endothelial growth factor concentrations and ovarian stromal flow are increased in women with polycystic ovaries. Hum Reprod 1998, | 3:651-655

40. Lara HE, Dissen GA, Leyton V, Paredes A, Fuenzalida H, Fiedler JL, Ojeda SR: An increased intraovarian synthesis of nerve growth factor and its low affinity receptor is a principal component of steroid-induced polycystic ovary in the rat. Endocrinology 2000, 141:1059-1072.

41. Campos X, Munoz Y, Selman A, Yazigi R, Moyano L, WeinsteinOppenheimer C, Lara HE, Romero C: Nerve growth factor and its high-affinity receptor trkA participate in the control of vascular endothelial growth factor expression in epithelial ovarian cancer. Gynecol Oncol in press. 2006, Aug 24

42. Anderson RA, Robinson LL, Brooks J, Spears N: Neurotropins and Their Receptors Are Expressed in the Human Fetal Ovary. J Clin Endocrinol Metab 2002, 87:890-897.

43. Abir R, Fisch B, Jin S, Barnnet M, Ben-Haroush A, Felz C, Kessler-lcekson G, Feldberg D, Nitke S, Ao A: Presence of NGF and its receptors in ovaries from human fetuses and adults. Mol Hum Reprod 2005, I I:229-236.

44. Salas C, Julio-Pieper M, Valladares M, Pommer R, Vega M, Mastronardi C, Kerr B, Ojeda SR, Lara HE, Romero C: Nerve growth factordependent activation of trkA receptors in the human ovary results in synthesis of FSH receptors and estrogen secretion. J Clin Endocrinol Metab 2006, 9 I:2396-2403.

45. Zhang L, Yang N, Conejo Garcia JR, Mohamed A, Benencia F, Rubin SC, Allman D, Coukos G: Generation of a syngeneic mouse model to study the effects of vascular endothelial growth factor in ovarian carcinoma. Am J Pathol 2002, I 6 I:2295-2309.

46. Qu Q, Perälä-Heape M, Kapanen A, Dahllund J, Salo J, Väänänen HK, Härkönen P: Estrogen enhances differentiation of osteoblasts in mice bone marrow culture. Bone 1998, 22:201-209.

47. Dissen GA, Parrott JA, Skinner MK, Hill DF, Costa ME, Ojeda SR: Direct effects of nerve growth factor on thecal cells from antral ovarian follicles. Endocrinology 2000, I 4 I:4736-4750. 